\title{
Financial and Institutional Support Are Important for Large-Scale Kelp Forest Restoration
}

\author{
Aaron M. Eger ${ }^{1 *}$, Adriana Vergés 1,2 , Chang Geun $\mathrm{Choi}^{3}$, Hartvig Christie 4 , \\ Melinda A. Coleman ${ }^{5}$, Camilla W. Fagerli4, Daisuke Fujita ${ }^{6}$, Masatoshi Hasegawa $^{7}$, \\ Jeong Ha Kim ${ }^{8}$, Mariana Mayer-Pinto ${ }^{1,2}$, Dan C. Reed ${ }^{9}$, Peter D. Steinberg ${ }^{1,2,10}$ and \\ Ezequiel M. Marzinelli2,10,11
}

${ }^{1}$ Centre for Marine Science and Innovation \& Evolution and Ecology Research Centre, School of Biological, Earth and Environmental Sciences, The University of New South Wales, Sydney, NSW, Australia, ${ }^{2}$ Sydney Institute of Marine Science, Mosman, NSW, Australia, ${ }^{3}$ Department of Ecological Engineering, Pukyong National University, Busan, South Korea, ${ }^{4}$ Norwegian Institute for Water Research, Oslo, Norway, ${ }^{5}$ Department of Primary Industries, New South Wales (NSW) Fisheries, Coffs Harbour, NSW, Australia, ${ }^{6}$ School of Marine Bioresources, Applied Phycology, University of Tokyo Marine Science and Technology, Tokyo, Japan, ${ }^{7}$ Shizuoka Prefectural Research Institute of Fishery, Shimoda, Japan, ${ }^{8}$ Department of Biological Sciences, Sungkyunkwan University, Suwon-si, South Korea, ${ }^{9}$ Marine Science Institute, University of California, Santa Barbara, Santa Barbara, CA, United States, ${ }^{10}$ Singapore Centre for Environmental Life Sciences

OPEN ACCESS

Edited by:

Wen-Cheng Wang,

National Taiwan Normal University, Taiwan

Reviewed by: Elena Gissi,

Università luav di Venezia, Italy Manuel R. Guariguata,

Center for International Forestry

Research (CIFOR), Indonesia

${ }^{*}$ Correspondence:

Aaron M. Eger

aaron.eger@unsw.edu.au

Specialty section:

This article was submitted to

Marine Conservation

and Sustainability,

a section of the journal

Frontiers in Marine Science

Received: 15 February 2020 Accepted: 03 September 2020

Published: 25 September 2020

Citation:

Eger AM, Vergés A, Choi CG,

Christie H, Coleman MA, Fagerli CW,

Fujita D, Hasegawa M, Kim JH,

Mayer-Pinto M, Reed DC,

Steinberg $P D$ and Marzinelli EM

(2020) Financial and Institutional

Support Are Important

for Large-Scale Kelp Forest

Restoration.

Front. Mar. Sci. 7:535277.

doi: 10.3389/fmars.2020.535277
Engineering, Nanyang Technological University, Singapore, Singapore, ${ }^{11}$ School of Life and Environmental Sciences, Coastal and Marine Ecosystems, The University of Sydney, Sydney, NSW, Australia

Kelps form extensive underwater forests that underpin valuable ecosystem goods and services in temperate and polar rocky coastlines globally. Stressors, such as ocean warming and pollution are causing regional declines of kelp forests and their associated services worldwide. Kelp forest restoration is becoming a prominent management intervention, but we have little understanding of what drives restoration success at appropriate spatial scales. Though most restoration guidelines stress the importance of planning, stressor mitigation and ecological knowledge, other factors, such as lack of resources or institutional support are rarely discussed despite being potentially critical to achieving desired restoration outcomes. In this paper, we work to understand the importance of finances and institutions in the context of four of the world's largest kelp restoration projects. These projects span four countries, six kelp genera and were initiated in response to different causes of decline. We argue that to restore kelp at desired scales, adequate financing, and institutional support are critical to overcome ecological and environmental limitations. Acknowledging limitations, we outline ways to mobilize resources and encourage institutions to support kelp restoration.

Keywords: kelp, restoration, success, large scale, transplants, coastal management, urchins

\section{INTRODUCTION}

Kelp forest restoration (Orders Laminariales and Fucales) aims to reverse the loss of these ecologically and economically important coastal ecosystems (Dayton, 1985; Wernberg et al., 2019). To be successful, restoration projects must first mitigate or remove the cause of decline, which can include ocean warming, overgrazing, habitat destruction, pollution, and overfishing (Steneck et al., 2002; Vergés et al., 2014; Wernberg et al., 2019). If there is sufficient propagule supply, removing grazers (North, 1978; Fujita, 2010; Tracey et al., 2015), adding hard substrate (Carlisle et al., 1964), remediating water quality (Driskell et al., 2001), or a combination of each, may be enough to 
restore populations (Reed et al., 2004; Foster and Schiel, 2010). Additional actions are required when local propagule supply is insufficient or recruitment is limited (North, 1978; Campbell et al., 2014). Methods to overcome these barriers include introducing reproductive material or donor plants into degraded areas via seeding or transplanting (Carney et al., 2005; Verdura et al., 2018). Notwithstanding these advances in the field, most kelp restoration projects to date have been small scale $\left(<100 \mathrm{~m}^{2}\right)$, short in duration ( $<2$ years), and academically motivated (Eger et al., 2020; Morris et al., 2020). As a result, questions remain about how the field of kelp restoration can meet its goal of restoring populations at scales that match those of degradation or loss.

General ecosystem restoration principles are well-established and can help guide kelp restoration (Figure 1). These steps are extensively discussed elsewhere (Hobbs and Harris, 2001; Gann et al., 2019), but briefly involve: (1) defining clear goals and criteria to evaluate success, which then allows for (2) designing and (3) implementing the project, followed by (4) evaluating programs to determine if the performance criteria are met. If criteria are not met, these previous steps allow for (5) identifying reasons for failure and (6) using adaptive management to remediate the project to meet its goals (Figure 1). While the ecological barriers and methodological steps to restoration are often well-defined, the social, governance, and financial barriers to restoration typically receive less attention and are the focus of this perspective.

Past research has demonstrated how substantial financial resources are needed to support restoration activity and how institutions can provide the logistical, legal, and social framework to initiate and sustain restoration activity. Ecosystem restoration is cost and labor intensive, with median costs of 10 s of thousands USD (2010) per hectare in terrestrial systems (De Groot et al., 2013) and 100s of thousands of USD in marine ecosystems (Bayraktarov et al., 2016). Indeed, many marine restoration projects have been flagged as too expensive to implement (Yeemin et al., 2006; Bellwood et al., 2019). Each step involved in restoration projects requires funding (Figure 1) and failure to finance any step is likely to compromise further steps and undermine the success of the whole project. Therefore, largescale marine restoration projects require considerable financial inputs. Furthermore, failing to engage with the local stakeholders who interact with the ecosystem is likely to negatively influence the success of projects. Hence, restoration projects must consider social aspects to achieve long term success (Abelson et al., 2016; Budiharta et al., 2016). Such aspects are particularly complex in marine ecosystems as these have multiple resource users and restoration sites are often in the public domain (Ruddle et al., 1992; Ounanian et al., 2018).

Strong institutional support (national, regional, or local) can help remove socio-economic barriers. First, trusted institutions, such as NGOs, private industry, and community groups have significant social influence and can increase community support for projects (Voyer and van Leeuwen, 2019) while making sure the projects meet the needs of the community. Second, government institutions often have considerable resources to fund projects (Meyers et al., 2020). They also have the legal authority to mandate restoration, work within maritime laws, and incentivize restoration projects (Clewell and Aronson, 2006).

Here, we take a case study approach to examine the role of financial and institutional support in four of the largest kelp restoration projects documented to date. We identified projects with the largest area resorted (110-21,000 ha) by querying the results of a kelp restoration database which contains multilanguage published and unpublished records of kelp restoration projects from 1957 to 2020 (Eger et al., 2020). The selected projects are in California (United States), Norway, Korea, and Japan, and span six genera of macroalgae. Kelp loss in these areas was due to water pollution, herbivore grazing and urban development, and restoration was done through the use of transplants, seeding, and herbivore removal, as well as deployment of artificial reefs (Figure 2).

\section{LARGE-SCALE RESTORATION PROJECTS}

\section{Wheeler North Reef, Southern California, United States}

Discharge of cooling water from the San Onofre Nuclear Generating Station (SONGS) in southern California caused the loss of 73 ha of giant kelp Macrocystis pyrifera. To offset this damage, the State of California mandated the utility company that owned SONGS to: (1) construct an artificial reef that was large enough to replace the kelp forest destroyed by SONGS' operations, and (2) provide funding for independent monitoring to ensure that the artificial reef maintains similar ecological levels of kelp and fauna as adjacent natural reefs while also meeting absolute targets to offset the losses of the initial reef (Songs Experimental Reef Permit E-97-10 Adopted Findings, 1999). Practitioners built the SONGS artificial reef, named "Wheeler North Reef," in three phases. The first phase started in 1999, and spent 5-years testing the efficacy of different reef designs to restore kelp (Reed et al., 2004, 2006). The monitoring results from this first phase were used to inform the design of the second phase: an additional 62 ha of reef. Ten years of additional monitoring showed that while the reef had similar kelp density and biota composition to nearby natural reefs, it did not meet the absolute standing stock standards for giant kelp and reef fish because the reef was deemed to be too small (Schroeter et al., 2018). In response, the state of California required the owners of SONGS to construct a third phase of the project (2019-2020) that added 85 ha of quarry rock reef. The resulting 156 ha reef extends along $7 \mathrm{~km}$ of coast and is one of the world's largest man-made rocky reefs. Cost estimates of the construction and monitoring of Phases 1 and 2 is tens of millions of USD, with monitoring costing $\sim$ \$1 million USD/year while the estimated construction costs for Phase 3 are between \$17.62-\$27.89 million (USD, 2010; Southern California Edison, 2017).

\section{Urchin Culling, Northern Norway}

During the 1970s, population expansions of sea urchins (Strongylocentrotus droebachiensis) formed grazing fronts 


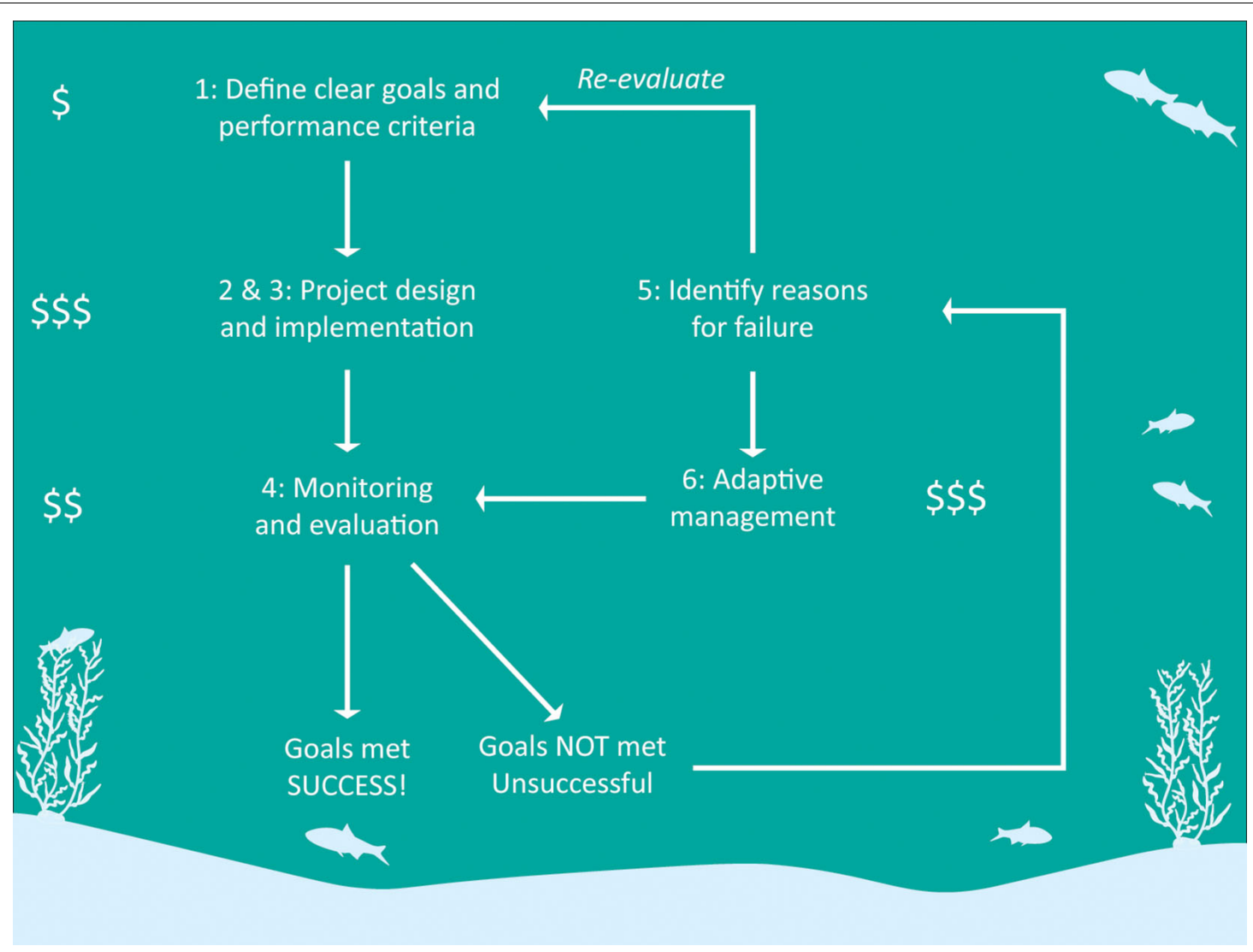

FIGURE 1 | Flow chart of best-practice steps involved in restoration projects. Dollar signs indicate the relative costs of each step.

that transformed approximately 900,000 ha of kelp forest along the northern coast of Norway into persistent urchin barrens (Norderhaug and Christie, 2009). In 2011, a pilot project involving local authorities, research institutions, and industry tested whether the use of quicklime $(\mathrm{CaO})$, which dissolves urchin tests on contact, had any unintended environmental impacts in Porsanger Fjord. After 1 year, cover of macroalgae and kelp increased, and the method was then scaled up in Porsanger in year $2(\sim 30 \mathrm{ha})$ and replicated in nearby Hammerfest over an area of $\sim 80$ ha in 2017 (Strand et al., 2020). These efforts resulted in the return of the kelps Saccharina latissima and Alaria esculenta and increases in faunal biodiversity. The estimated cost of applying quicklime over 100 ha was $\$ 130,000$ (USD, 2010), but the Norwegian Research Council provided substantial additional funds for pilot projects, monitoring, and research between 2011 and 2017.

\section{Marine Restoration Program, Korea}

Kelp declines along the east coast of Korea have been mostly caused by sea urchin grazing, resulting in the loss of Sargassum spp., Undaria pinnatifida, and Saccharina spp. On the south coast and off the island of Jeju, urchins are absent and declines of Ecklonia spp., Sargassum spp., and U. pinnatifida are mainly due to coastal development and habitat loss. These deforested areas increased rapidly in the 1990s and individual restoration efforts first began in 2002 (Choi et al., 2003).

In 2009 , the government sought to upscale initial restoration efforts and established a national research fund for kelp restoration. The project has been managed by two government bodies, first the National Institute of Fisheries Science (NIFS) and later by the Korea Fisheries Resource Agency (FIRA). The project also partnered with Sungkyunkwan University and Pukyong National University to evaluate the status of kelp beds and urchin barrens, and to develop new restoration techniques. This initiative aims to restore 54,000 ha of kelp forests (Park et al., 2019) by the year 2030 and to enhance fisheries in Korea.

The project focuses on deploying concrete artificial reefs in areas with low urchin density (Jeon et al., 2015) in combination with juvenile kelp transplants, seeding (spore bags), and/or urchin removal, and subsequent monitoring. As of 2019, reefs and transplants were deployed over an area of approximately 21,489 ha (Park et al., 2019; Hwang et al., 2020) with a survival rate of $\sim 50 \%$ (Jeon, 2019, personal communication). Artificial reefs were originally used because the agency believed that transplanting kelp onto rock covered by crustose coralline algae would limit success, but new methods are being developed to deploy transplants onto natural rocky reefs. The final goal involves restoration at 260 locations across the coast and a budget of \$267 million (USD, 2010) for the years 2015-2030. 


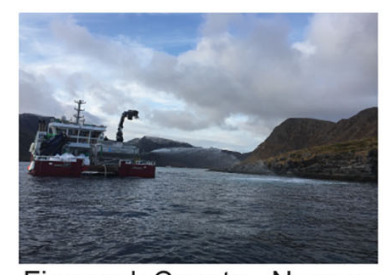

Finnmark County - Norway 110 Hectares

$>$ \$0.13 Million

6 years

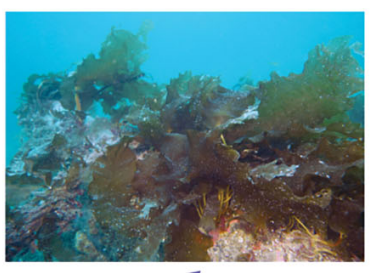

1
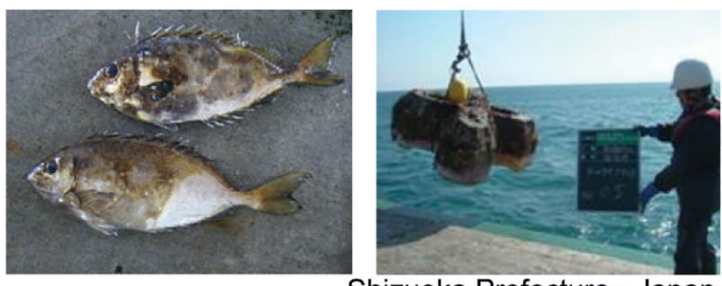

Shizuoka Prefecture - Japan 870 Hectares $\$ 5.21$ Million 16 years

\section{Decline \\ Method

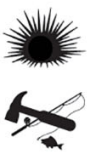

All Coasts - Korea 21, 489 Hectares $>$ \$267 Million 11 (21 more planned)
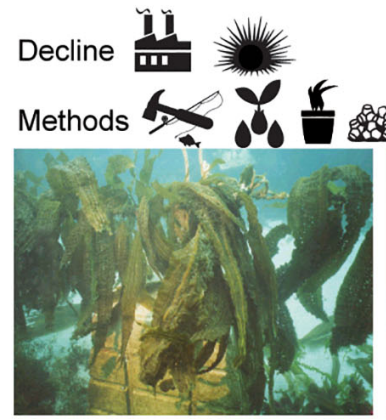
的的

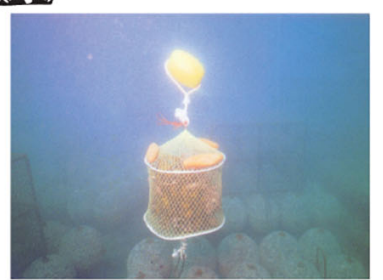

FIGURE 2 | Location, methods, cause of decline, size, and costs of the four large scale kelp restoration case studies. All costs are reported in USD for the year 2010 .

\section{Transplants, Shizuoka Prefecture, Japan}

Increased turbidity and browsing by herbivores contributed to the decline of 8,000 ha of Ecklonia cava and Eisenia nipponica beds in Hainan, Japan between 1985 and 2000 (Hasegawa, 2010). As a result, the wild Eisenia and abalone fisheries closed and interest in renewing these resources soon followed (Unnno et al., 2010). In 1999, the Shizuoka Prefectural Government started initial restoration efforts by transplanting small concrete blocks into nearby Ecklonia beds to accumulate sporophytes, which were then relocated to the target site in the Hainan area. Initially, this work was successful, but within three years, herbivorous fish (e.g., Siganus fuscescens) grazed the transplants. A second, larger attempt then followed. Instead of seeding blocks in the field, Ecklonia sporophytes were mass cultured using a deep-sea water circulation system and attached to 2,162 concrete blocks, which were then placed onto natural rocky reefs. Placing the transplants on the blocks elevated the plants off benthos, a place where they are vulnerable to increased turbidity. In addition, the governing bodies paid local fishermen to remove herbivorous fish. This attempt was supported by local fishery cooperative, the municipal, prefectural, and national governments, which each provided logistical support and financial resources. The project ran between 2002 and 2010, with a budget of $\$ 5.21$ million (USD, 2010). Following continued efforts, monitoring shows the project has restored approximately 870 ha of kelp habitat as of 2018 and fisheries cooperatives are now considering the re-opening of the abalone fishery.

\section{PROJECT COMMONALITIES}

Subtidal coastal restoration is a complex and expensive enterprise that is estimated to cost thousands to millions of dollars (USD, 2010) per hectare (Bayraktarov et al., 2016). Restoring kelp forests is no exception and actions, such as urchin culling, kelp cultivation, outplanting, and reef building are both time and resource intensive. Projects described here had budgets from $\$ 5$ to $\$ 267$ million USD (2010), which also allowed them to run for extended periods of time ( $>6$ years). In addition, all four projects were managed by multipartite partnerships from 
universities, industry, and government agencies. We believe that strong financial and institutional support, typically by government, enabled these projects to conduct kelp restoration on such large scales.

\section{Supporting Best Practices in Restoration}

Though high levels of investment do not guarantee success (Bayraktarov et al., 2016), they enable projects to follow best practices for restoration. In all the described projects, funding over an extended period allowed managers to develop and test methodologies, assess initial results and alter the approach taken based on evidence. For example, the urchin culling efforts in Norway repeatedly tested the potential impacts and efficacy of the quicklime approach before investing further resources and upscaling the project. Although the planning stages of a project (Figure 1-1) represent a small part of the overall budget, they are important to ensure an effective framework for restoration (Figure 1). Because populations take several years to establish and even longer for a full ecosystem to return (Carter et al., 1985; Tegner et al., 1997) monitoring is required over an extended period of time. In the Wheeler North Reef project, extensive monitoring revealed that although kelp recruited on the reef within 9 months, the kelp biomass failed to offset the original estimated losses of kelp and fish biomass, even 12 years after restoration. Moreover, adaptive management is only feasible if active monitoring occurs. Adaptive management can be vital to the success of a project and may often be the most expensive step because it requires effective monitoring and quick mobilization of resources to address the detected problems (Figure 1-6).

Having multiple groups from different sectors involved in the restoration process can help reduce individual costs per group and draw on different areas of expertise (Gann et al., 2019). All four projects were the result of multiple collaborations between different stakeholders from academia to government to industry, with government participation being the one common partner group across the four projects. This commonality suggests that working with relevant government agencies can help achieve restoration at meaningful scales. This may be because government bodies lend legitimacy to the project (Van Tatenhove, 2011), provide legal backing (Lausche and Burhenne-Guilmin, 2011) and secure sustained funding (Waldron et al., 2013). Involvement from academia can help develop methodologies while locally based groups can ensure that the project has the support and is meeting the needs of the community.

Just as financial and institutional support can enable project success, their absence can lead to failure. Early efforts (19591976) in Southern California were initially successful in restoring patches of Macrocystis, but insecure funding resulted in sporadic maintenance of the sites and, eventually, project termination. Where restoration projects were not completed, sites often returned to their unrestored condition (Wilson and North, 1983). Indeed, many projects often run by volunteers and funded with donations have had to cease operations as funding depleted (Eger et al., 2020). Regulations meant to protect ocean resources can also hinder projects. For example, working to install kelp transplants or seeding is subject to stringent environmental reviews in most locations around the world and this poses as a barrier to entry for many groups (Pace and Morgan, 2016). Nevertheless, working within such regulations will help ensure that restoration activities are conducted in a safe and ethical manner but factors, such as an expedited review process for urgent environmental decisions and modifications to regulations to facilitate a future of increasing restoration must be considered.

\section{Mobilizing Financial and Institutional Support for Large Scale Restoration}

Developing strategies to enhance financial and institutional support for kelp forest restoration is critical for the success of large-scale restoration projects. Financial support often flows from institutional support, i.e., once institutions are motivated, they will fund restoration, not vice versa. There are many levers that can be pulled to increase this support. First, most institutions will only invest in an enterprise if it is understood to benefit them. Currently, the benefits of kelp forest ecosystems are poorly understood, and institutions are therefore reticent to invest in their restoration (De Groot et al., 2013). Therefore, a key first step in increasing support for restoration is quantifying and promoting the value of ecosystem services in kelp forests (see early work in Vásquez et al., 2014; Blamey and Bolton, 2018) and then integrating those values into government decision making processes. This connection is well-demonstrated in Korea and Japan where both countries have strong socio-economic ties to the ocean and have invested millions of dollars into restoration (Bestor and Bestor, 2014).

International frameworks and agreements can also be used to mobilize resources. For instance, the Global Oceans Accounts Partnership (GOAP) ${ }^{1}$ provides an initial framework for quantifying ecosystem services and using the economic values in decision making. GOAP has support from the UN-ESCAP, Fisheries and Oceans Canada, the World Bank, and is being piloted in 11 countries (Global Ocean Accounts Partnership, 2019). Other multi-national organizations and agreements can also be used to further restoration. The UN Decade on Ecosystem Restoration and the UN Decade of Ocean Science for Sustainable Development were agreed to by all 193 UN member states and provide paired international imperatives to set binding targets for kelp forest restoration. These international targets should motivate national restoration projects.

Creating and reinforcing environmental protection laws and mandating development projects to mitigate and offset damages to marine habitat will help institutionalize restoration that may otherwise not occur (Akhtar-Khavari and Richardson, 2019). The benefits of these requirements were well-demonstrated in Wheeler North Reef restoration project. The utility company was legally required to offset habitat losses from the operation of their commercial activities. Many countries currently have offsetting laws (Niner et al., 2017) but few kelp restoration projects have been completed in response to development projects that destroyed habitat (Eger et al., 2020). This gap suggests that kelp maybe an overlooked habitat with regard to offsetting.

\footnotetext{
${ }^{1}$ www.oceanaccounts.org
} 
Financing for future kelp restoration projects will likely come from a mix of for-profit (e.g., industry) and nonprofit (e.g., governments, universities, NGOs, philanthropies) funds and initiatives. Investments from non-profit sources are likely to be motivated by the provision of publicly available ecosystem services, such as fisheries and cultural values. Whereas profit driven funding will require private financial returns. Mechanisms like payments for ecosystem services and blue bonds (Salzman et al., 2018) can be used to attract for-profit funding to restoration projects (Thiele and Gerber, 2017). In other instances, businesses may invest in ventures that generate a commodity, such as sea urchin roe or the kelp itself but still work to restore wild populations (Gentry et al., 2020). Some of these ventures will be purely private whereas others will be mixture of private and public funds (i.e., blended finance, Rode et al., 2019).

\section{CONCLUSION}

Financial and institutional support of kelp restoration projects appear to be critical to enable kelp restoration at relevant scales. These supports are in addition to, not replacement of, good planning and ecological understanding of the system and are crucial at most, if not all, steps of the restoration process (Figure 1). Encouragingly, we show that with the appropriate financial and institutional support, successful kelp restoration is achievable at large scales. Fortunately, there are several ways to gain such support, including clearly demonstrating the ecological and socio-economic values of the services provided by ecosystems. Financial and institutional support will become more important in the future as ocean ecosystems change and new solutions to sustain them are required (Coleman and Goold, 2019).

\section{REFERENCES}

Abelson, A., Halpern, B. S., Reed, D. C., Orth, R. J., Kendrick, G. A., Beck, M. W., et al. (2016). Upgrading marine ecosystem restoration using ecological-social concepts. Bioscience 66, 156-163. doi: 10.1093/biosci/biv171

Akhtar-Khavari, A., and Richardson, B. J. (2019). Ecological Restoration Law: Concepts and Case Studies. Abingdon: Routledge. doi: 10.4324/9780429468315

Bayraktarov, E., Saunders, M. I., Abdullah, S., Mills, M., Beher, J., Possingham, H. P., et al. (2016). The cost and feasibility of marine coastal restoration. Ecol. Appl. 26, 1055-1074. doi: 10.1890/15-1077

Bellwood, D. R., Pratchett, M. S., Morrison, T. H., Gurney, G. G., Hughes, T. P., Álvarez-Romero, J. G., et al. (2019). Coral reef conservation in the Anthropocene: confronting spatial mismatches and prioritizing functions. Biol. Conserv. 236, 604-615. doi: 10.1016/j.biocon.2019.05.056

Bestor, V. L., and Bestor, T. C. (2014). Japan and the Sea. Educ. about Asia 19:2.

Blamey, L. K., and Bolton, J. J. (2018). The economic value of South African kelp forests and temperate reefs: past, present and future. J. Mar. Syst. 188, 172-181. doi: 10.1016/j.jmarsys.2017.06.003

Budiharta, S., Meijaard, E., Wells, J. A., Abram, N. K., and Wilson, K. A. (2016). Enhancing feasibility: incorporating a socio-ecological systems framework into restoration planning. Environ. Sci. Policy 64, 83-92. doi: 10.1016/j.envsci.2016. 06.014

Campbell, A. H., Marzinelli, E. M., Vergés, A., Coleman, M. A., and Steinberg, P. D. (2014). Towards restoration of missing underwater forests. PLoS One 9:e84106. doi: 10.1371/journal.pone.0084106

\section{DATA AVAILABILITY STATEMENT}

All datasets analyzed for this study are included in the article/supplementary material.

\section{AUTHOR CONTRIBUTIONS}

AE, AV, DR, PS, MM-P, and EM conceived the idea for the manuscript. $\mathrm{AE}$ and EM led the writing. $\mathrm{CF}$ and $\mathrm{HC}$ wrote the Norway section. MH and DF wrote the Japan section. JK and CC wrote the Korea section. DR wrote the California section. AE, AV, MC, MM-P, PS, and EM wrote the first draft. All authors provided comments, edited, and approved the full manuscript for submission.

\section{FUNDING}

This work was supported by Australian Research Council grants DP180104041 (PS and EM) and LP160100836 (PS, EM, AV, and $\mathrm{MC})$. The University of New South Wales supported AE with a Scientia Ph.D. Scholarship.

\section{ACKNOWLEDGMENTS}

We would like to thank the Shizuoka Prefectural Government (Japan) for providing two photos used in Figure 2. The vector graphics were adapted from The Integration and Application Network, University of Maryland Center for Environmental Science (http://ian.umces.edu/imagelibrary/). We also thank the editors of this special issue who provided a valuable platform to discuss marine restoration, and reviewers for their valuable comments.

Carlisle, J. G., Turner, C. H., and Ebert, E. E. (1964). Artificial Habitat in the Marine Environment. Sacramento, CA: Resources Agency of California.

Carney, L. T., Waaland, J. R., Klinger, T., and Ewing, K. (2005). Restoration of the bull kelp Nereocystis luetkeana in nearshore rocky habitats. Mar. Ecol. Prog. Ser. 302, 49-61. doi: 10.3354/meps302049

Carter, J. W., Carpenter, A. L., Foster, M. S., and Jessee, W. N. (1985). Benthic succession on an artificial reef designed to support a kelp-reef community. Bull. Mar. Sci. 37, 86-113.

Choi, C. G., Kim, H. G., and Sohn, C. H. (2003). Transplantation of young fronds of Sargassum horneri for construction of seaweed beds. Korean J. Fish. Aquat. Sci. 36, 469-473. doi: 10.5657/kfas.2003.36.5.469

Clewell, A. F., and Aronson, J. (2006). Motivations for the restoration of ecosystems. Conserv. Biol. 20, 420-428. doi: 10.1111/j.1523-1739.2006.00 340.x

Coleman, M. A., and Goold, H. D. (2019). Harnessing synthetic biology for kelp forest conservation1. J. Phycol. 55, 745-751. doi: 10.1111/jpy.12888

Dayton, P. K. (1985). Ecology of kelp communities. Annu. Rev. Ecol. Syst. 16, 215-245. doi: 10.1146/annurev.es.16.110185.001243

De Groot, R. S., Blignaut, J., Van Der Ploeg, S., Aronson, J., Elmqvist, T., and Farley, J. (2013). Benefits of investing in ecosystem restoration. Conserv. Biol. 27, 1286-1293. doi: $10.1111 /$ cobi. 12158

Driskell, W. B., Ruesink, J. L., Lees, D. C., Houghton, J. P., and Lindstrom, S. C. (2001). Long-term signal of disturbance: Fucus gardneri after the exxon valdez oil spill. Ecol. Appl. 11, 815-827. doi: 10.1890/1051-0761(2001)011[0815: LTSODF]2.0.CO;2 
Eger, A. M., Marzinelli, E., Steinberg, P., and Vergés, A. (2020). Worldwide synthesis of kelp forest reforestation. Open Sci. Framew. 1-8.

Foster, M. S., and Schiel, D. R. (2010). Loss of predators and the collapse of southern California kelp forests: alternatives, explanations and generalizations. J. Exp. Mar. Biol. Ecol. 393, 59-70. doi: 10.1016/j.jembe.2010.07.002

Fujita, D. (2010). Current status and problems of isoyake in Japan. Bull. Fish. Res. Agen. 32, 33-42.

Gann, G. D., McDonald, T., Walder, B., Aronson, J., Nelson, C. R., Jonson, J., et al. (2019). International principles and standards for the practice of ecological restoration. Restor. Ecol. 27, S3-S46. doi: 10.1111/rec.13035

Gentry, R. R., Alleway, H. K., Bishop, M. J., Gillies, C. L., Waters, T., and Jones, R. (2020). Exploring the potential for marine aquaculture to contribute to ecosystem services. Rev. Aquac. 12, 499-512. doi: 10.1111/raq.12328

Global Ocean Accounts Partnership (2019). Technical Guidance on Ocean Accounting for Sustainable Development, 1st Edn. (New York, NY: United Nations).

Hasegawa, M. (2010). Isoyake studies in Shizuoka Prefecture. Japan. Bull. Fish Res. Agen. 32, 109-114.

Hobbs, R. J., and Harris, J. A. (2001). Restoration ecology: repairing the earth's ecosystems in the new millennium. Restor. Ecol. 9, 239-246. doi: 10.1046/j. 1526-100x.2001.009002239.x

Hwang, E. K., Choi, H. G., and Kim, J. K. (2020). Seaweed resources of Korea. Botanica Marina 63, 395-405. doi: 10.1515/bot-2020-0007

Jeon, B. H., Yang, K. M., and Kim, J. H. (2015). Changes in macroalgal assemblage with sea urchin density on the east coast of South Korea. Algae 30:139. doi: 10.4490/algae.2015.30.2.139

Lausche, B. J., and Burhenne-Guilmin, F. (2011). Guidelines for Protected Areas Legislation. Gland: IUCN.

Meyers, D., Alliance, C. F., Bohorquez, J., Cumming, B. F. I. B., Emerton, L., Riva, M., et al. (2020). Conservation finance: a framework. Conserv. Finance Allian. 1-45. doi: 10.13140/RG.2.2.14186.88000

Morris, R. L., Hale, R., Strain, E. M. A., Reeves, S., Verges, A., Marzinelli, E. M., et al. (2020). Key principles for managing recovery of kelp forests through restoration. Bioscience 70, 688-698. doi: 10.1093/biosci/biaa058

Niner, H. J., Milligan, B., Jones, P. J. S., and Styan, C. A. (2017). A global snapshot of marine biodiversity offsetting policy. Mar. Policy 81, 368-374. doi: 10.1016/ j.marpol.2017.04.005

Norderhaug, K. M., and Christie, H. C. (2009). Sea urchin grazing and kelp re-vegetation in the NE Atlantic. Mar. Biol. Res. 5, 515-528. doi: 10.1080/ 17451000902932985

North, W. J. (1978). Evaluation, Management, and Cultivation of Macrocystis Kelp Forests. in (United States). Available online at: https://www.osti.gov/servlets/ purl/5007205 (accessed January 10, 2020).

Ounanian, K., Carballo-Cárdenas, E., van Tatenhove, J. P. M., Delaney, A., Papadopoulou, K. N., and Smith, C. J. (2018). Governing marine ecosystem restoration: the role of discourses and uncertainties. Mar. Policy 96, 136-144. doi: 10.1016/j.marpol.2018.08.014

Pace, N. L., and Morgan, N. (2016). Living shorelines: eroding regulatory barriers to coastal resilience. Nat. Resources Env't 31:44.

Park, K.-Y., Kim, T.-S., Jang, J.-C., and Kang, J. W. (2019). "Marine forest reforestation project of Korea Fisheries Resources Agency (FIRA)," in Proceedings of the 23rd International Seaweed Symposium (Jeju: International Seaweed Association).

Reed, D. C., Schroeter, S. C., Huang, D., Anderson, T. W., and Ambrose, R. F. (2006). Quantitative assessment of different artificial reef designs in mitigating losses to kelp forest fishes. Bull. Mar. Sci. 78, 133-150.

Reed, D. C., Schroeter, S. C., and Raimondi, P. T. (2004). Spore supply and habitat availability as sources of recruitment limitation in the giant kelp Macrocystis pyrifera (Phaeophyceae) 1. J. Phycol. 40, 275-284. doi: 10.1046/j.1529-8817. 2004.03119.x

Rode, J., Pinzon, A., Stabile, M. C. C., Pirker, J., Bauch, S., Iribarrem, A., et al. (2019). Why 'blended finance'could help transitions to sustainable landscapes: lessons from the unlocking forest finance project. Ecosyst. Serv. 37:100917. doi: 10.1016/j.ecoser.2019.100917

Ruddle, K., Hviding, E., and Johannes, R. E. (1992). Marine resources management in the context of customary tenure. Mar. Resour. Econ. 7, 249-273. doi: 10.1086/ mre.7.4.42629038

Salzman, J., Bennett, G., Carroll, N., Goldstein, A., and Jenkins, M. (2018). The global status and trends of Payments for Ecosystem Services. Nat. Sustain. 1, 136-144. doi: 10.1038/s41893-018-0033-0
Schroeter, S. C., Reed, D. C., and Raimondi, P. T. (2018). Artificial reefs to mitigate human impacts in the marine environmen: the wheeler north reef as a test case. Am. Fish. Soc. Symp. 86, 197-213.

Songs Experimental Reef Permit E-97-10 Adopted Findings (1999). Monitoring Plan for the Songs Reef Mitigation Project. San Francisco, CL: California Coastal Commision.

Southern California Edison (2017). Rebuttal Testimony of Southern California Edison in Support of the Joint Application for Cost Recovery of the Wheeler North Reef Expansion Project Marine Mitigation Costs. Rosemead, CL: Southern California Edison.

Steneck, R. S., Graham, M. H., Bourque, B. J., Corbett, D., Erlandson, J. M., Estes, J. A., et al. (2002). Kelp forest ecosystems: biodiversity, stability, resilience and future. Environ. Conserv. 29, 436-459. doi: 10.1017/S0376892902000322

Strand, H. K., Christie, H. C., Fagerli, C. W., Mengede, M., and Moy, F. E. (2020). Optimizing the use of quicklime $(\mathrm{CaO})$ for sea urchin decimation - a lab and field study. Ecol. Eng. 1-10. doi: 10.1016/j.ecoena.2020.100018

Tegner, M. J., Dayton, P. K., Edwards, P. B., and Riser, K. L. (1997). Largescale, low-frequency oceanographic effects on kelp forest succession: a tale of two cohorts. Mar. Ecol. Prog. Ser. 146, 117-134. doi: 10.3354/meps14 6117

Thiele, T., and Gerber, L. R. (2017). Innovative financing for the high seas. Aquat. Conserv. Mar. Freshw. Ecosyst. 27, 89-99. doi: 10.1002/aqc.2794

Tracey, S. R., Baulch, T., Hartmann, K., Ling, S. D., Lucieer, V., Marzloff, M. P., et al. (2015). Systematic culling controls a climate driven, habitat modifying invader. Biol. Invasions 17, 1885-1896. doi: 10.1007/s10530-015-0845-Z

Unnno, Y., Hasegawa, M., Unno, Y., and Hasegawa, M. (2010). Restoration of ecklonia cava forest on hainan coast, Shizuoka prefecture. Bull. Fish. Resour. Agency 32, 119-124.

Van Tatenhove, J. (2011). Integrated marine governance: questions of legitimacy. Mast 10, 87-113.

Vásquez, J. A., Zuñiga, S., Tala, F., Piaget, N., Rodríguez, D. C., and Vega, J. M. A. (2014). Economic valuation of kelp forests in northern Chile: values of goods and services of the ecosystem. J. Appl. Phycol. 26, 1081-1088. doi: 10.1007/ s10811-013-0173-6

Verdura, J., Sales, M., Ballesteros, E., Cefalì, M. E., and Cebrian, E. (2018). Restoration of a canopy-forming alga based on recruitment enhancement: methods and long-term success assessment. Front. Plant Sci. 9:1832. doi: 10. 3389/fpls.2018.01832

Vergés, A., Steinberg, P. D., Hay, M. E., Poore, A. G. B., Campbell, A. H., Ballesteros, E., et al. (2014). The tropicalization of temperate marine ecosystems: climate-mediated changes in herbivory and community phase shifts. Proc. R. Soc. B Biol. Sci. 281:20140846. doi: 10.1098/rspb.2014.0846

Voyer, M., and van Leeuwen, J. (2019). 'Social license to operate'in the blue economy. Resour. Policy 62, 102-113. doi: 10.1016/j.resourpol.2019.02.020

Waldron, A., Mooers, A. O., Miller, D. C., Nibbelink, N., Redding, D., Kuhn, T. S., et al. (2013). Targeting global conservation funding to limit immediate biodiversity declines. Proc. Natl. Acad. Sci. U.S.A. 110, 12144-12148. doi: 10.1073/pnas.1221370110

Wernberg, T., Krumhansl, K., Filbee-Dexter, K., and Pedersen, M. F. (2019). "Status and trends for the world's kelp forests," in World Seas: An Environmental Evaluation, ed. C. Sheppard (Amsterdam: Elsevier), 57-78. doi: 10.1016/b9780-12-805052-1.00003-6

Wilson, K. C., and North, W. J. (1983). A review of kelp bed management in southern California. J. World Maric. Soc. 14, 345-359. doi: 10.1111/j.17497345.1983.tb00089.x

Yeemin, T., Sutthacheep, M., and Pettongma, R. (2006). Coral reef restoration projects in Thailand. Ocean Coast. Manag. 49, 562-575. doi: 10.1016/j. ocecoaman.2006.06.002

Conflict of Interest: The authors declare that the research was conducted in the absence of any commercial or financial relationships that could be construed as a potential conflict of interest.

Copyright $\odot 2020$ Eger, Vergés, Choi, Christie, Coleman, Fagerli, Fujita, Hasegawa, Kim, Mayer-Pinto, Reed, Steinberg and Marzinelli. This is an open-access article distributed under the terms of the Creative Commons Attribution License (CC BY). The use, distribution or reproduction in other forums is permitted, provided the original author(s) and the copyright owner(s) are credited and that the original publication in this journal is cited, in accordance with accepted academic practice. No use, distribution or reproduction is permitted which does not comply with these terms. 